\title{
Prioritization of Revenue Management Factors: A Synthetic Extent Analysis Approach
}

\author{
Getiri Yönetimi Faktörlerinin Önceliklendirilmesi: Sentetik Kapsam Analizi Yaklaşımı
}

\section{Mehmet Emre GÜLER ${ }^{1}$}

\begin{abstract}
Purpose: This paper presents a novel approach for revealing the success factors of revenue management practices in hospitality industry. Our study aims to point out the favorably contributing 'ingredients' of a successful revenue management application. We investigate what revenue managers have learned from their past experience by using real empirical data and fuzzy synthetic evaluation procedure. Researchers and practitioners may regard this work as a functional benchmark analyzing a function (revenue management) which is widely used in those companies belongs to a particular industry (hospitality industry).
\end{abstract}

Design/methodology/approach: Revenue managers'judgments about the underlying success factors are highly subjective and qualitative in nature. In order to capture this imprecision, we employed the fuzzy synthetic extent analysis and provided with a sensible prioritization of the success factors.

Research limitations/implications: Employing fuzzy concepts within a prioritization procedure requires constructing a fuzzy linguistic variable set and as-signing a fuzzy conversion scale to it. Usually the implementation steps in fuzzy techniques are more cumbersome when compared to the conventional multi attribute techniques (i.e. conventional AHP).

Originality/value: This paper discusses the prioritization of effective factors that concede to a successful revenue management application in hospitality industry with a synthetic extent analysis approach. This paper provides with a 'snapshot' of the current practice in the area and serves for researchers and practitioners.

Keywords: Fuzzy prioritization, synthetic extent analysis, revenue management, hospitality industry.

\section{INTRODUCTION}

Today's managers have to realize that contriving to control their costs is not alone sufficient to succeed in the current intense competition, yet, simultaneously they have to find a means of controlling their revenues as well. The latter task is more involved, as it is highly dependent on uncontrollable external factors rather than the 'inbound and hence manageable' ones. The companies offering perishable products or services (i.e. storage for future possible sale is impossible) and

\section{ÖZET}

Amaç: Bu makale, konaklama sektöründe getiri yönetimi uygulamalarının başarı faktörlerini ortaya çıkarmak için yeni biryaklaşım sunmaktadır. Çalışmada, başarılı bir getiri yönetimi uygulamasına olumlu katkı verecek içerikler belirlenmeye çalışılmıştır. Getiri yönetimi uygulayıcılarının deneyimlerinden faydalanılarak elde edilen ampirik verilerin analizinden sonra bulanık sentetik değerlendirme prosedürü uygulanmıştır. Bu çalışma birçok farklı sektörde (konaklama sektörü) kullanılabilecek fonksiyonel karşılaştırma analizinin (getiri yönetimi) bir örneği olarak araştırmacı ve uygulamacıların ilgisini çekebilir.

Tasarım/Metodoloji/Yaklaşım: Çalışmada geçen başarı faktörleri ile ilgili olarak getiri yönetimi uygulamacılarının deneyimleri ve yargıları subjektiftir. Buradan hareketle, çalışmada uygulanan bulanık sentetik analizi ile başarı faktörlerinin daha mantıksal bir önceliklendirilmesi sağlanmaya çalışılmıştır.

Araştırma Sınırlamaları/Etkileri: Önceliklendirme prosedürü ile bulanık kavramların uygulanması, bulanık dil değişkenlerinin belirlenmesi ve bunların bulanık ölçekte dönüşümünü gerektirmektedir. Genelde bulanık teknikleri uygulama adımları çok kriterli karşılaştırma teknikleri (AHP) için uygulanması zordur.

Özgünlük/Değer: Bu çalışma konaklama endüstrisinde başarılı getiri yönetimi uygulamaları için etkili olan faktörlerin önceliklendirmesi için sentetik kapsam analizinin kullanımını ortaya koymaktadır. Bununla birlikte, çalışma, mevcut uygulamalara bir bakış açısı sunmaktadır.

Anahtar Kelimeler: Bulanık önceliklendirme, sentetik kapsam analizi, getiri yönetimi, konaklama endüstrisi

those operate with fixed capacities are much sensitive to external uncontrollable factors. Typical companies having these properties are the airline companies and hotels.

Revenue Management System is used for determining the state in desirable time in the future with using past data and reviewing present state and estimating future. This system is widely used in service sector as hospitality and airline industry but also used in some solving methods for problems 
cited in literature as capacity estimating and assignment problem (Modarres and Sharifyazdi, 2009), determining service flow and price between the wholesaler and retailer in supply chain (Hu et.al., 2009), optimization of airline pricing system with linear programming (Topaloğlu, 2008), optimization of flight reservation and selling inventory with the customer satisfaction (Lindenmeier and Tscheulin, 2008) and developing pricing strategy in remanufactured product (Mitra, 2007).

\section{LITERATURE REVIEW}

The studies on critical success factors in revenue management are encountered in literature. Griffin (1995) investigated critical success factors with 27 variables for rooms to let and defined five factors as system classification, user training, user characteristics, organizational support and external environment. Hansen and Eringa (1998) studied critical success factors on revenue management using structural equation modeling. The model was formed with relationship between organization of revenue management function, authorization, employee behavior, revenue management system and percentage of income. The other study on difficulties of revenue management approach and critical success factors were studied in small and medium hotel enterprises in Florence (Luciani, 1999). This investigation was framed three main topics listed below:

- Knowledge of respondent about revenue management,

- Decision support system of human resource, technology and information system in hotel and

- Strategic and tactical decision making system

Upchurch et.al. (2002) made an exploratory analysis in revenue management approach used a questionnaire form to revenue management managers and front desk officer. As a result of this analysis, they exposed a critical success factor into five topics as revenue management (short term), demand indicator (mid-term), benchmarking, demand forecasting (long term) and supply-demand maximization.

\subsection{Preliminaries}

Since the analytic hierarchy process (AHP) was first introduced in the late 1970s (Saaty, 1977; Saaty, 1980), it gained widely acceptance by many researchers and have been applied to several areas ranging from supplier selection to common vote prediction. It has been primarily designed to guide decision makers coping with multiple criteria decision situations. Readers interested in the mathematical theory behind AHP and its applications are referred to (Saaty, 1980; Zahedi, 1996; Vaidya and Kumar, 2006). Managerial judgments as articulated by pair-wise comparisons are the fundamental inputs for facilitating the AHP procedure. Each pair-wise comparison results in a numerical value aij representing the ratio between the weights of the two criteria defined by $\mathrm{i}$ and $j$. AHP method employs crisp values from Saaty's static nine-point fundamental scale. However, when the decision maker's judgments are uncertain, obtaining such precise crisp values may be very difficult. Therefore, static crisp values may lack the ability to capture the decision makers' blurred preferences. A logical way to overcome this limitation is to define the comparison ratios as being fuzzy numbers.

A triangular fuzzy number $F$ is a fuzzy set and its membership function $\mu_{F}(x)$ is a piece-wise linear function having following properties:

(1) $F$ is a particular subset of $\mathfrak{R}$;

(2) $\mu_{\mathrm{F}}(x)$ is a continuous mapping from $\Re$ to the closed interval $[0,1]$;

(3) $\mu_{\mathrm{F}}(\mathrm{x})=0$ for all $x \mathrm{G}\left(-\infty, \mathrm{I}_{\mathrm{F}}\right] \cup\left[\mathrm{u}_{\mathrm{F}^{\prime}}+\infty\right)$ and $\mu_{\mathrm{F}}(\mathrm{x})=$ 1 for $\mathrm{x}=m_{F}$ where $I_{f^{\prime}} m_{p} u_{F} \in d_{t^{\prime}} l_{F}$ and $u_{F}$ are the lower and upper limits and $m_{F}$ is the most likely value of $F$, respectively;

(4) $\mu \mathrm{F}(\mathrm{x})$ is monotonically increasing when $x$ $\in\left[I_{p} m_{F}\right]$ and monotonically decreasing when $x \in$ $\left[m_{p} u_{p}\right]$.

In this article, we characterize the comparison ratios between the success factors $i$ and $j$ with triangular fuzzy numbers which describes the judgment 'about $a_{i j}{ }^{\prime}$ and denote them with $\tilde{a}_{i j}$. Hence, we were able to describe some degree of blurred human perception about the corresponding pairwise comparison. Next, we introduce particular linguistic assessment terms, so called 'fuzzy linguistic variables', to represent the underlying fuzzy numbers employed for factor evaluations.

A fuzzy linguistic variable is an expression in natural or artificial language (Zadeh, 1975) which describes a collection of values. For our purposes, we em $\neg$ ployed five fuzzy linguistic variables to help the decision maker describe his/her subjective judgment about the relative importance of a factor versus another. These linguistic variables are: equally important, moderately important, more important, 
Table 1: Fuzzy Linguistic Variable Set and Their Underlying Fuzzy Numbers

\begin{tabular}{|l|c|c|l|}
\hline $\begin{array}{c}\text { Linguistic } \\
\text { Variable }\end{array}$ & $\begin{array}{c}\text { Fuzzy } \\
\text { Number }\end{array}$ & $\begin{array}{c}\text { Membership } \\
\text { Function }\end{array}$ & \multicolumn{1}{c|}{ Definition } \\
\hline $\begin{array}{l}\text { Equally } \\
\text { important }\end{array}$ & $\tilde{1}$ & $(1,1,2)$ & $\begin{array}{l}\text { Practical knowledge and experience assert that factor } i \text { is equally } \\
\text { important when compared to factor } j .\end{array}$ \\
\hline $\begin{array}{l}\text { Moderately } \\
\text { important }\end{array}$ & $\tilde{3}$ & $(2,3,4)$ & $\begin{array}{l}\text { Practical knowledge and experience assert that factor } i \text { seems } \\
\text { moderately more important when compared to factor } j .\end{array}$ \\
\hline $\begin{array}{l}\text { More } \\
\text { important }\end{array}$ & $\tilde{5}$ & $(4,5,6)$ & $\begin{array}{l}\text { Practical knowledge and experience assert that factor } i \text { is more } \\
\text { important when compared to factor } j .\end{array}$ \\
\hline $\begin{array}{l}\text { Strongly } \\
\text { important }\end{array}$ & $\tilde{7}$ & $(6,7,8)$ & $\begin{array}{l}\text { Practical knowledge and experience assert that factor } i \text { is strongly } \\
\text { important when compared to factor } j .\end{array}$ \\
\hline $\begin{array}{l}\text { Extremely } \\
\text { important }\end{array}$ & $\tilde{9}$ & $(8,9,9)$ & $\begin{array}{l}\text { Practical knowledge and experience assert that factor } i \text { is } \\
\text { extremely important when compared to factor } i \text {, and totally } \\
\text { outweighs it. }\end{array}$ \\
\hline
\end{tabular}

strongly important and extremely important. In Table 1 , we illustrate a summary of our fuzzy linguistic variable set with lower, most likely and upper values of underlying triangular fuzzy numbers and their definitions.

Introduction of fuzzy linguistic variables instead of exact crisp values will enable the decision maker to use non-numerical terms and it can incorporate the imprecision related to decision maker's preference, thus it eliminates the drawback of the static structure of the fundamental scale of AHP in capturing uncertainty related to pair-wise comparisons.

Fuzzy set theory bears a resemblance to the logical behavior of human brain faced with imprecision. For example, when the conditions in the financial market start to get risky, rather than giving exact investment decisions, people prefer to allocate the subject capital into several investment alternatives and prefer to 'fuzzify' their investment decisions by allocating less to risky instruments, more on promising instruments and the largest part to the mostly regarded alternative. For example, in case of high risk, one may choose to allocate less to stocks, more to governmental bonds and the largest part to overnight instruments as a consequence of rational behavior. This way of thinking is due to inherent response characteristic of human brain towards ambiguity in the decision situation. The idea of generalizing the crisp descriptions to fuzzy descriptions in order to capture human reasoning better is applicable to many methods in operations research. Parallel to many fuzzy extensions of other operational research methods, a fuzzy version of the AHP was developed by Van Laarhoven and Pedrycz (1983), who studied with triangular membership functions and compared underlying fuzzy ratios.

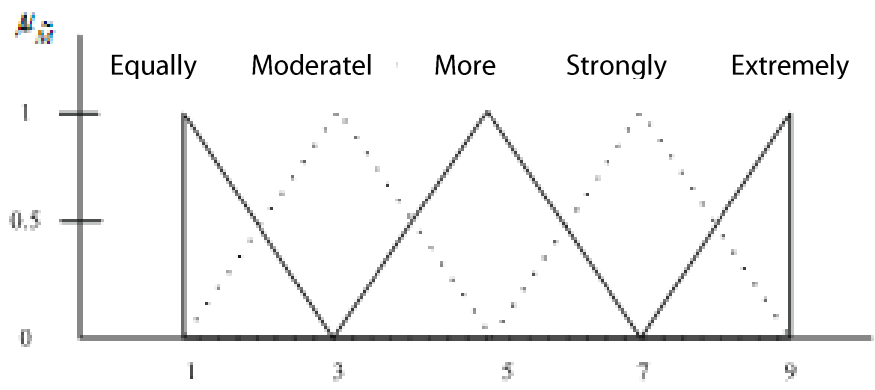

Figure 1: Linguistic Variables for the Importance Weight of Each Criterion

Since they introduced the fuzzy AHP modeling, several authors contributed both with conceptual and application oriented papers. Among the conceptual papers, Buckley (1985) derived fuzzy comparison priorities from trapezoidal membership functions, Boender et al. (1989) proposed an approach for local priority normalization and Leung and Cao (2000) discussed the consistency and ranking issues contributing with a consistency definition. The method was successfully applied for evaluating different production cycle alternatives (Weck et al., 1997), priority setting for software development process (Lee et al., 1999), evaluating military systems (Cheng et al., 1999), technology selection (Chan et al., 2000), customer satisfaction measurement (Cebeci and Kahraman, 2002), location decisions (Kuo et al., 2002) and facilitating quality function deployment procedure (Kwong and Bai, 2002), multi-criteria inventory classification (Cakir and Canbolat, 2008). 
The essential step in Fuzzy AHP methodology is the prioritization procedure. The prioritization problem is defined as deriving the unknown priority column vector $P=\left[p_{j}\right]^{T}, i=1, \ldots, n$ from the judgment set $\tilde{A}=\left[\tilde{a}_{i j}\right], i, j=1, \ldots, n$ where the pair-wise comparisons are fuzzy numbers given by $\tilde{a}_{i j}=\left(l_{i j} m_{i j} u_{i j}\right)$ and $\mathrm{pi}$ denote the priority of factor $i$. There are several approaches for deriving priorities from fuzzy pair-wise comparison matrices. Logarithmic least squares method (Van Laarhoven and Pedrycz, 1983), geometric mean method (Buckley, 1985), interval arithmetic (Cheng and Mon, 1994), synthetic extent analysis (Chang, 1996), fuzzy least squares method $(\mathrm{Xu}, 2000)$ and fuzzy preference programming (Mikhailov, 2003) are some notable techniques of prioritization. For our prioritization problem, we selected Chang's synthetic extent analysis approach which is an ingenious technique and well suited for studying with triangular fuzzy numbers.

\section{METHODOLOGY}

Synthetic extent analysis is one of the most popular fuzzy prioritization methods. The permutation of the decision elements is very similar to conventional AHP and the two methods almost have equal implementation steps. First, pair-wise comparisons are carried out using triangular fuzzy numbers. Then, the synthetic extent value Si of each element is found. Next step is to calculate the nonnormalized weights by applying the principle of fuzzy number comparison (Chang, 1996). The last step is to normalize the weights found for each decision element. In what follows, we briefly summarize the synthetic extent analysis procedure.

Consider an object set of $\mathrm{n}$ objects indexed by $i$ and a goal set of $m$ goals indexed by $j$. The idea is to take each object and perform extent analysis with respect to each goal. We end up with having $m$ extent analysis values $e_{i}^{j}, i=1, \ldots, n ; j=1, \ldots, m$ where each $e_{i}^{j}$ value is a triangular fuzzy number characterized by three parameters (lij, mij, uij). Then, the synthetic extent value regarding to the $i^{\text {th }}$ objective is given by:

$$
S_{i}=\sum_{j=1}^{m} e_{i}^{j} \otimes\left(\sum_{i=1}^{n} \sum_{j=1}^{m} e_{i}^{j}\right)^{-1}
$$

where $\otimes$ is the the fuzzy multiplication operator and additions are performed using the fuzzy addition operator. Therefore, for the first term in the above formula, we have

$$
\begin{aligned}
& \sum_{j=1}^{m} e_{i}^{j}=\left(\sum_{j=1}^{m} l_{j}, \sum_{j=1}^{m} m_{j}, \sum_{j=1}^{m} u_{j}\right), \forall i=1, \ldots, n \\
& \text { and for the second term, we have } \\
& \left(\sum_{i=1}^{n} \sum_{j=1}^{m} e_{i}^{j}\right)^{-1}=\frac{1}{\sum_{i=1}^{n} \sum_{j=1}^{m} u_{i}}, \frac{1}{\sum_{i=1}^{n} \sum_{j=1}^{m} m_{i}}, \\
& \frac{1}{\sum_{i=1}^{n} \sum_{j=1}^{m} l_{i}} .
\end{aligned}
$$

These calculations are the natural outcomes of fuzzy operational laws and quite different from regular additions and multiplications. The readers further interested in the main operational laws of triangular fuzzy numbers are referred to (Kaufmann and Gupta, 1991).

Next, consider two fuzzy numbers $F_{1}=\left(l_{1}, m_{1}, u_{1}\right)$ and $F_{2}=\left(I_{z^{\prime}} m_{2^{\prime}} u_{2}\right)$. For a sensible comparison between these two fuzzy numbers, we have to investigate both the degree of possibility that $F_{1}$ is bigger than or equal to $F_{2}$ and the degree of possibility that $F 1$ is smaller than or equal to $F_{2}$. Let $D\left(F_{1} \geq F_{2}\right)$ denote the degree of possibility that $F_{1}$ is bigger than or equal to $F_{2}$. We have three possible cases for $D\left(F_{1} \geq F_{2}\right)$ :

Case 1: If $u_{1} \leq I_{2}$, then we have $D\left(F_{1} \geq F_{2}\right)=0$.

Case 2: If $m_{1} \geq m_{2^{\prime}}$ then we have $D\left(F_{1} \geq F_{2}\right)=1$.

Case 3: For all other possible cases the corresponding degree of possibility is given by

$$
D(F 1 \geq F 2)=\frac{l_{2}-u_{1}}{\left(m_{1}-u_{1}\right)-\left(m_{2}-l_{2}\right)} .
$$

For a logical comparison, Chang (1996) uses the degree of possibility that a fuzzy number $F_{i}$ to be greater than $k$ fuzzy numbers. This term can be written as follows

$$
\begin{aligned}
D\left(F_{i} \geq F_{1}, \ldots, F_{k}\right)= & \left(D\left(F_{i} \geq F_{1}\right) \wedge\left(F_{i} \geq F_{2}\right) \wedge \ldots\right. \\
& \left.\wedge D\left(F_{i} \geq F_{k}\right)\right) .
\end{aligned}
$$

The principle of fuzzy number comparison (Chang, 1996) states that the degree of possibility that a fuzzy number $\mathrm{Fi}$ is greater than o $\mathrm{f}$ equal to a set of fuzzy numbers is equal to the minimum degree of possibility among these values. Therefore, we have

$D\left(F_{i} \geq F_{1}, \ldots, F_{k}\right)=\min \left(D\left(F_{i} \geq F_{j} \mid j=1, \ldots, k\right)\right.$.

After stating the fuzzy number comparison principles, we recall our prioritization problem characterized by an ( $n x n)$ fuzzy comparison matrix. Consider the synthetic extent values $\mathrm{Si}$ found from such matrix using equation (1). Let $h_{i}=\min \left(D\left(S_{i} \geq S_{j} \mid j=1, \ldots, n ; j \neq i\right)\right.$ and note that $\mathrm{h}$ is the 
projection of the highest intercept point of two membership functions on the number axis. Then we have a non-normalized priority vector for $n$ elements:

$$
P^{\prime}=\left[h_{1}, \ldots, h_{n}\right]^{T} \text {. }
$$

The priority vector is calculated with normalizing the components of this vector $\left(\right.$ i.e. $\left.p_{i}=h_{i} \mid \sum_{(i=1)}^{n} h_{i}\right)$ :

$$
P=\left[p_{1}, \ldots, p_{n}\right]^{T} .
$$

\subsection{Prioritizing Revenue Management Success Factors}

In this section we illustrate how fuzzy concepts can be used with real empirical data to reveal the success factors of revenue management in hospitality industry. In the first step of this study, a study was conducted with 460 hotel managers that operates in Aegean region, which is a popular touristic area located at southwest coast of Turkey. In this study, the sample was diverse in terms of the hotel size and location, number of employees, operating budget and annual revenues generated. We employed

\begin{tabular}{|c|c|}
\hline Factor Group & Success Indicators within Factor Group \\
\hline $\begin{array}{c}\text { Internal Benchmarks } \\
\begin{aligned} \propto & =0.924 \\
\sigma_{p}^{2} & =22.077\end{aligned}\end{array}$ & $\begin{array}{l}\text { Match the room rate to market demand } \\
\text { Arrival and departure patterns by market segments } \\
\text { Identify local or citywide events } \\
\text { Understand pricing temperament of transient travelers } \\
\text { Review group activities so as to identify current booking pattern } \\
\text { Establishment of an overbooking policy } \\
\text { Utilize demand tracking reporting to predict patterns of demand } \\
\text { Utilize demand tracking reporting to predict early departure patterns } \\
\text { Know when to close reservation arrival dates } \\
\text { Know when to require a minimum length of stay }\end{array}$ \\
\hline $\begin{array}{l}\text { Market Analysis } \\
\qquad \begin{aligned} \propto & =0.934 \\
\sigma_{p}^{2} & =18.441\end{aligned}\end{array}$ & $\begin{array}{l}\text { Conduct a periodic check of competitor's occupancy percentage } \\
\text { Determine special promotions } \\
\text { Implementation of an overbooking policy } \\
\text { Determine when discount rates should be closed while maintaining a sufficient } \\
\text { room supply for rack rate guests } \\
\text { Limit the room capacity and denial reservations if the rate does not meet the high } \\
\text { rate during peak season } \\
\text { Review of no-show pattern } \\
\text { Be able to forecast future lengths of stay } \\
\text { Be able to project demand for future rate types }\end{array}$ \\
\hline $\begin{array}{l}\text { Demand Forecasting } \\
\qquad \begin{aligned} \propto & =0.907 \\
\sigma_{p}^{2} & =16.290\end{aligned}\end{array}$ & $\begin{array}{l}\text { Review historical booking performance to identify future forecasting patterns } \\
\text { Understand pricing temperament of group travelers } \\
\text { Utilize demand tracking reporting to predict no-show patterns } \\
\text { Keep track of all reservation denials on a daily basis } \\
\text { Utilize demand tracking reporting to predict cancellation } \\
\text { Adjust prices to suit market demand and booking policies specific to high and low } \\
\text { demand cycles } \\
\text { Review of historical demand } \\
\text { Conduct a periodic check of competitor's rates } \\
\text { Be able to match room rate to market demand }\end{array}$ \\
\hline 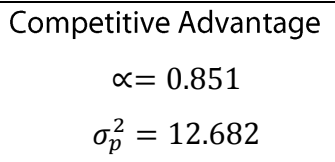 & $\begin{array}{l}\text { Determine last minute rates } \\
\text { Be able to project demand for future arrival dates } \\
\text { Know when to eliminate or restrict discount allocations } \\
\text { Determine discount structure }\end{array}$ \\
\hline 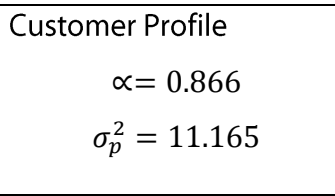 & $\begin{array}{l}\text { Review of walk-in pattern } \\
\text { Length of guest stay } \\
\text { Review of reservation cancellation pattern } \\
\text { Tracking of seasonal cycles } \\
\text { Be able to project demand for future room types }\end{array}$ \\
\hline
\end{tabular}

Table 2: Results of Factor Analysis 
several 36 success indicators (Upchurch, 2002) and surveyed managers' opinions about the contribution of these indicators to the revenue management practices. Then we conducted a factor analysis as a preprocessing step to group these indicators into factor groups. We used Cronbach's a to test the reliability of our grouping scheme. In Table 2 success indicators are illustrated and grouped into 5 major factor groups.

We tried as much as possible to name the factor groups regarding to the common characteristics of the indicators contained within that group. Thus, we labeled our factor groups as: Internal Benchmarks $(I B)^{\prime}$, 'Market Analysis (MA)', 'Demand Forecasting (DF)', 'Competitive Advantage (CA)', and 'Customer Profile $(C P)$ '. The $a$ values shown under each factor group is the corresponding Cronbach's a reliability coefficient.
The $a$ values for each factor group indicate a high degree of reliability with our scale and found to be sufficient for our grouping scheme's internal consistency. The $\sigma_{p}^{2}$ values are the percentage variances explained by each factor group. We were able to explain $80,655 \%$ of the total variance with these 36 indicators. We discarded a few remaining indicators due to the factor analysis results.

After this preprocessing step, we asked the respondent managers to compare factor groups using our fuzzy linguistic variable set illustrated in Table 1. Since it is not practical to conduct a Delphi type controlled group process with such a big sample size, we used the modal values of the judgments acquired by this procedure. Hence, we were able to construct the fuzzy linguistic pair-wise comparison matrix as illustrated in Table 3.

Table 3: Fuzzy Linguistic Pair-Wise Comparison Matrix

\begin{tabular}{|l|c|c|c|c|c|}
\hline & IB & MA & DF & CA & CP \\
\hline IB & Equal & & Equally imp. & Equally imp. & Strongly imp. \\
\hline MA & Moderately imp. & Equal & & More imp. & Extremely imp. \\
\hline DF & & Moderately imp. & Equal & Extremely imp. & More imp. \\
\hline CA & & & & Equal & \\
\hline CP & & & & More imp. & Equal \\
\hline
\end{tabular}

Using the information in Table 1 and Table 3, we can generate the fuzzy pair-wise comparison matrix with the underlying triangular fuzzy numbers. The fuzzy pair-wise comparison matrix is illustrated in
Table 4. The elements located symmetrically along the diagonal of this matrix are simply the fuzzy reciprocals of each other.

Table 4: Fuzzy Pair-Wise Comparison Matrix

\begin{tabular}{|l|c|c|c|c|c|}
\hline & IB & MA & DF & CA & CP \\
\hline IB & $(1,1,1)$ & $(1 / 4,1 / 3,1 / 2)$ & $(1,1,2)$ & $(1,1,2)$ & $(6,7,8)$ \\
\hline MA & $(2,3,4)$ & $(1,1,1)$ & $(1 / 4,1 / 3,1 / 2)$ & $(4,5,6)$ & $(8,9,9)$ \\
\hline DF & $(1 / 2,1,1)$ & $(2,3,4)$ & $(1,1,1)$ & $(8,9,9)$ & $(4,5,6)$ \\
\hline CA & $(1 / 2,1,1)$ & $(1 / 6,1 / 5,1 / 4)$ & $(1 / 9,1 / 9,1 / 8)$ & $(1,1,1)$ & $(1 / 4,1 / 3,1 / 2)$ \\
\hline CP & $(1 / 8,1 / 7,1 / 6)$ & $(1 / 9,1 / 9,1 / 8)$ & $(1 / 6,1 / 5,1 / 4)$ & $(2,3,4)$ & $(1,1,1)$ \\
\hline
\end{tabular}

The next step is to calculate synthetic extent values corresponding to each factor. By applying formula (1), we have:

$$
\begin{gathered}
S_{I B}=(5.5,7.5,9.5) \otimes\left(\frac{1}{37.167}, \frac{1}{27.235}, \frac{1}{20.234}\right)=(0.148,0.2754,0.4695) \\
S_{M A}=(3.4,4.667,6.167) \otimes\left(\frac{1}{37.167}, \frac{1}{27.235}, \frac{1}{20.234}\right)=(0.0915,0.1714,0.3048)
\end{gathered}
$$




$$
\begin{gathered}
S_{D F}=(5.167,7,9.5) \otimes\left(\frac{1}{37.167}, \frac{1}{27.235}, \frac{1}{20.234}\right)=(0.139,0.257,0.4695) \\
S_{C A}=(3.167,4.334,6.5) \otimes\left(\frac{1}{37.167}, \frac{1}{27.235}, \frac{1}{20.234}\right)=(0.0852,0.1591,0.3212) \\
S_{C P}=(3,3.734,5.5) \otimes\left(\frac{1}{37.167}, \frac{1}{27.235}, \frac{1}{20.234}\right)=(0.0807,0.1371,0.2718)
\end{gathered}
$$

Next, using the principle of fuzzy number comparison, we calculate the degrees of possibilities

$$
\begin{gathered}
D\left(S_{I B} \geq S_{M A}\right)=1, D\left(S_{I B} \leq S_{M A}\right)=0.6012 \\
D\left(S_{I B} \geq S_{D F}\right)=1, D\left(S_{I B} \leq S_{D F}\right)=0.9459 \\
D\left(S_{I B} \geq S_{C A}\right)=1, D\left(S_{I B} \leq S_{C A}\right)=0.5983 \\
D\left(S_{I B} \geq S_{C P}\right)=1, D\left(S_{I B} \leq S_{C P}\right)=0.4723 \\
D\left(S_{M A} \geq S_{D F}\right)=1, D\left(S_{M A} \leq S_{D F}\right)=0.6595
\end{gathered}
$$

Next, using the principle of fuzzy number comparison, we calculate the degrees of possibilities

$$
\begin{gathered}
\min _{i}\left\{D\left(S_{I B} \geq S_{i}\right)\right\}=1 \\
\min _{i}\left\{D\left(S_{M A} \geq S_{i}\right)\right\}=0.6012 \\
\min _{i}\left\{D\left(S_{D F} \geq S_{i}\right)\right\}=0.9459
\end{gathered}
$$

According to these possibilities, the nonnormalized priority vector is calculated as $\mathrm{P}=1,0.601$ $2,0.9459,0.5983,0.4723)$. With normalizing this vector, we arrive at the priority vector: $\mathrm{P}=(0.277,0.166,0.262$ $, 0.165,0.130$ ). According to the prioritization values found, the most important factors contributing to a successful revenue management application are Internal Benchmarks and Demand Forecasting. Subsequent to these, Market Analysis and Competitive Advantage are the equally important contributors. Lastly, Customer Profile is found to have a lower level of priority when compared to above factors. Some indicators clustered in the most important factor, Internal Benchmarks' indicators imply that the most important qualifications that a hotel must acquire are to fully understand its own capabilities and the ability to analyze the outcomes of its own past revenue management decisions. It is evident that customer segmentation is vital for facilitating a sensible revenue management policy, hence with considering three possible cases as discussed in previous section:

$$
\begin{aligned}
& D\left(S_{M A} \geq S_{C A}\right)=1, D\left(S_{M A} \leq S_{C A}\right)=0.9492 \\
& D\left(S_{M A} \geq S_{C P}\right)=1, D\left(S_{M A} \leq S_{C P}\right)=0.8402 \\
& D\left(S_{D F} \geq S_{C A}\right)=1, D\left(S_{D F} \leq S_{C A}\right)=0.6505 \\
& D\left(S_{D F} \geq S_{C P}\right)=1, D\left(S_{D F} \leq S_{C P}\right)=0.5255 \\
& D\left(S_{C A} \geq S_{C P}\right)=1, D\left(S_{C A} \leq S_{C P}\right)=0.8945
\end{aligned}
$$

with considering three possible cases as discussed in previous section:

$$
\begin{aligned}
& \min _{i}\left\{D\left(S_{C A} \geq S_{i}\right)\right\}=0.5983 \\
& \min _{i}\left\{D\left(S_{C P} \geq S_{i}\right)\right\}=0.4723
\end{aligned}
$$

indicators such as 'arrival and departure patterns by market segments', 'Review historical booking performance to identify future forecasting patterns', 'Understand pricing temperament of group travelers', 'Conduct a periodic check of competitor's occupancy percentage', 'Identify local or citywide events' and 'Utilize demand tracking reporting to predict noshow pattern' are clustered in the first three factors having higher degree or priorities. Another point worthy for mention is that timing is crucial issue in all the revenue management and related operations as the indicators such as 'Arrival and departure patterns by market segments,' 'Tracking of seasonal cycles' and 'Length of guest stay' all lie in relatively important factor groups.

The indicators such as 'Review historical booking performance to identify future forecasting patterns' and 'Utilize demand tracking reporting to predict early departure patterns' justify that projecting the internal data for future expectations is essential 
for a hotel allotting itself for success in its revenue management operations. Customer Profile is regarded as lower priority factor by most of the managers as the indicators in this group are found to be relatively hard to facilitate in practice. These indicators are 'review of walk-in pattern', 'length of guest stay', 'review of reservation cancellation pattern' 'tracking of seasonal cycles' and 'be able to project demand for future room types'.

\section{CONCLUSIONS}

In this paper, we discussed a prioritization model based on empirical data on concepts from fuzzy AHP literature. We analyzed revenue management operations of 460 hotels located in Aegean Region, Turkey and presented our findings regarding to this study. Our prioritization scheme is comprised of 5 essential success factors and 36 indicators related to revenue management practices of the hotels within sample. On the other hand, in respect of fuzzy AHP ranking has a similarity with variance analysis. There is just a ranking difference between 'Market Analysis' and 'Demand Forecasting'. This similarity shows that experts and sample groups have concurrence of opinion.

The main purpose of this study is to provide an effective framework to guide the hotel managers and interested researchers for defining and prioritizing the success factors of revenue management. Although our results illustrate the current practice in Aegean Region, the model can be applied in any country with including region-specific other indicators. Furthermore, our scheme can be applied to other service industries with including industryspecific indicators.

Table 5: Comparison of Factor Ranking

\begin{tabular}{|c|c|}
\hline In Respect of Variance Analysis & In Respect of $F$-AHP Ranking \\
\hline Internal Benchmarks & Internal Benchmarks \\
\hline Market Analysis & Demand Forecasting \\
\hline Demand Forecasting & Market Analysis \\
\hline Competitive Advantage & Competitive Advantage \\
\hline Customer Profile & Customer Profile \\
\hline
\end{tabular}




\section{REFERENCES}

Buckley, J.J. (1985) "Fuzzy Hierarchical Analysis" Fuzzy Sets and Systems, 17:233-247.

Boender, C.G.E., Degrann, J.G. and Lootsma, F.A. (1986) "Multi-Criteria Decision Analysis with Fuzzy Pairwise Comparison" Fuzzy Sets and Systems 29:133-143.

Cakir, O., Canbolat, M. (2008) "A Web-Based Decision Support System For Multi-Criteria İnventory Classification Using fuzzy AHP Methodology" Expert System with Application, 35:1367-1378.

Cebeci, U., Kahraman, C. (2002) "Measuring Customer Satisfaction of Catering Service Companies Using Fuzzy AHP: The Case of Turkey" Proceedings of the International Conference on Fuzzy Systems and Soft Computational Intelligence in Management and Industrial Engineering, May 29-31, Istanbul.

Chan, F.T.S., Chan, M.H. and Tang N.K.H. (2000) "Evaluation Methodologies for Technology Selection" Journal of Materials Processing Technology, 107:330-337.

Chang, D.Y. (1996) "Applications of The Extent Analysis Method on Fuzzy AHP" European Journal of Operational Research, 95(3):649-655.

Cheng, C.H., Mon, D.L. (1994) "Evaluating Weapon System by Analytical Hierarchy Process Based on Fuzzy Scales" Fuzzy Sets and Systems, 63:1-10.

Cheng, C.H., Yang, K.L. and Hwang, C.L. (1999) "Evaluating Attack Helicopters By AHP Based on Linguistic Variable Weight" European Journal of Operational Research, 116(2):423-443.

Griffin, R. K. (1995) "A Categorization Scheme for Critical Success Factors of Lodging Yield Management Systems" International Journal of Hospitality Management, 14(3/4):325-338.

Hansen, C. N., Eringa, K. (1998) "Critical Success Factors in Yield Management: A Development and Analysis" Progress in Tourism and Hospitality Research, 4:229-244.

Hu, Q., Wei, Y. and Xia, Y. (2009) "Revenue Management for a Supply Chain with Two Streams of Customers" European Journal of Operational Research, 200(2):582-598.

Kaufmann, A., Gupta, M.M. (1991) Introduction to Fuzzy Arithmetic: Theory and Applications, New York,Van Nostrand Reinhold.

Kwong, C.K., Bai, H. (2002) "A fuzzy AHP Approach to the Determination of Importance Weights of Customer Requirements in Quality Function Deployment" Journal of Intelligent Manufacturing, 13:367-377.
Lee, M., Pham, H. and Zhang, X. (1999) "A Methodology for Priority Setting with Application to Software Development Process" European Journal of Operational Research, 118(2):375-389.

Leung, L.C., Cao, D. (2000) "On Consistency and Ranking of Alternatives in Fuzzy AHP" European Journal of Operational Research, 124(1):102-113.

Lindenmeier, J., Tscheulin, D. K. (2008) "The effects of Inventory Control and Denied Boarding on Customer Satisfaction: The Case of Capacity-Based Airline Revenue Management" Tourism Management, 29:32-43.

Luciani, S. (1999) "Implementing Yield management in small and Medium Sized Hotels: An Investigation of Obstacles and Success Factors in Florence Hotels" Hospitality Management, 18:129-142.

Mikhailov, L. (2003) "Deriving Priorities From Fuzzy Pairwise Comparison Judgments" Fuzzy Sets and Systems, 134:365-385.

Mitra, S. (2007) "Revenue Management for Remanufactured Products" Omega, 35(5):553-562.

Modarres, M., Sharifyazdi, M. (2009) "Revenue Management Apporach to Stochastic Capacity Allocation Problem" European Journal of Operational Research, 192:442-459.

Saaty, T.L. (1977) "Scaling Method for Priorities in Hierarchical Structure" Journal of Mathematical Psychology, 15(3):234-281.

Saaty, T.L. (1980) Multicriteria Decision Making: The Analytic Hierarchy Process, New York, McGraw-Hill.

Topaloglu, H. (2008) "On the Asymptotic Optimality of the Randomized Linear Program for Network Revenue Management" European Journal of Operational Research, 197(3):884-896.

Upchurch, R. S., Ellis, T. and Seo, J. (2002) "Revenue Management Underpinnings: An Exploratory Review" Hospitality Management, 21:67-83.

Vaidya, O.S., Kumar, S. (2006) "Analytic Hierarchy Process: An Overview of Applications" European Journal of Operational Research, 169(1):1-29.

Van Laarhoven, P.J.M. \& Pedrycz, W. (1983) "A Fuzzy Extension of Saaty's Priority Theory” Fuzzy Sets and Systems, 11:229-241. 
Weck, M., Klocke, F., Shell, H. and Renauver, E. (1997) "Evaluating Alternative Production Cycles Using The Extended Fuzzy AHP Method" European Journal of Operational Research, 100(2):351-366.

Xu, R. (2000) "Fuzzy Least Squares Priority Method in the Analytic Hierarchy Process" Fuzzy Sets and Systems, 112:359-404.
Zahedi, F. (1996) "The Analytic Hierarchy Process: A Survey of the Method and Its Applications" Interfacesi 16(4):96-108.

Zadeh, L.A. (1975) "The Concept of Linguistic Variable and Its Application to Approximate Reasoning" Information Sciences, 8(3): 199-249. 